\title{
The Layout and Internal Development of Celtic Fields: Structural and Relative Chronological Analyses of Three Danish Field Systems
}

\author{
Nina Helt Nielsen ${ }^{1,2}$, Mads Kähler Holst ${ }^{1,3}$, Ann Catherine Gadd ${ }^{4}$ and \\ KLAUS KäHLER Holst ${ }^{5}$ \\ ${ }^{1}$ Department of Archaeology, University of Aarhus, Hojbjerg, Denmark \\ ${ }^{2}$ Museum Silkeborg, Silkeborg, Denmark \\ ${ }^{3}$ Moesgaard Museum, Højbjerg, Denmark \\ ${ }^{4}$ Museum Midtjylland, Herning, Denmark \\ ${ }^{5}$ Department of Biostatistics, Copenhagen University, Denmark
}

The layout and development of field systems may reflect significant aspects of prehistoric societies such as agricultural strategies, use rights and inheritance practices. This article presents a method for analysing the developments of field systems in their entirety, based on a bierarchical sorting of field boundaries whose intersections have been used to define relations of equivalence and subordination. The formalized relational expression of the field system is analysed using a stochastic optimization algorithm. The method was successfully applied to three Danish Celtic fields from the Late Bronze/Early Iron Age, making it possible to identify five principles behind the layout: primary boundaries (probably established at community level), major parcels (administered at a household level), structured subdivisions (presumably related to inheritance), irregular subdivisions, and small-scale expansions of the field systems. The initial degree of regularity of the field systems seems to have influenced later modifications.

Keywords: field systems, Celtic fields, layout, inheritance, relative chronology, stochastic sorting, Late Bronze Age/Early Iron Age

\section{INTRODUCTION}

Field systems constitute a morphologically diverse and geographically-as well as chronologically_-widespread type of 'architectural' phenomenon, which has played a prominent role in the discussion of a diverse range of cultural aspects. These include agricultural strategies and intensification (Widgren, 1983; Fokkens, 1998: 121; Lang, 2007; Yates, 2007), development of communities and co-operative practices (Hansen, 1979; Donat, 1992), land division, land allotment, tenure, property rights or ownership (Hatt, 1939; Widgren, 1995; Gerritsen, 2003; Johnston, 2005; Wickstead, 2008), the use of standardized measurements (Hannerberg, 1955; Eir, 1982; Wickstead, 2008), and conceptions and inscriptions of landscape (Carlsson, 1979; Fleming, 1987; Brück, 2000; Fallgren, 2006; Chadwick, 2013; Løvschal, 2015). Common to many of these issues is a reference to dynamics of, or within, the field systems in the form of crop and fallow rotation, changing 
assignments of use rights or ownership, principles of layout, and extensions and reorganizations of the field systems. In general, however, only limited information on the actual development of field systems exists. Excavations, geoarchaeological analyses, and absolute dates can reveal information about formation and dynamics within field systems, including discontinuation, relocation, and addition of boundaries (e.g. Becker, 1972; Brück et al., 2003; Nielsen \& Clemmensen, 2010; Nielsen \& Dalsgaard, 2017); however, since the investigations generally only comprise minor proportions of extensive complexes, it is not possible through this approach to obtain insights into the internal development of field systems in their entirety.

Consequently, large-scale studies of dynamics of field systems have to rely primarily on analyses of the morphology of the systems in combination with assumptions on how to read them. Generally, attempts to identify overlaying chronologically distinct structures have been based on differences in overall morphological characteristics, such as shape and orientation of fields and size of field boundaries (e.g. Hatt, 1949: 129; Lindquist, 1974; Brongers, 1976; Lang, 1994). However, several research problems regarding field systems refer to their internal and gradual transformation and development. The most obvious examples are questions concerning the development of field systems, as in the discussion of planned layouts versus gradual growths of field systems (e.g. Sørensen, 1982; Fleming, 1987; Johnston, 2005; Chadwick, 2008, 2013; Nielsen \& Clemmensen, 2010), and in the suggested link between inheritance principles and the subdivision of field plots (Hatt, 1939; Riles, 1998).

Attempts have been made to identify large blocks or superior units within field systems, which were subsequently divided into fields (e.g. Fowler, 1971; Veibæk, 1974; Brongers, 1976; Bradley, 1978;
Carlsson, 1979). Although these did not include formalized analyses of the field systems, in practice, the identifications were based on a form of morphological syntax in which long continuous boundaries were considered primary, while boundaries joining these were regarded as secondary or dependent (e.g. Fowler, 1971: fig. 13; Brongers, 1976: pl. 15c). The identification was thus based on a form of $\mathrm{T}$-intersection hierarchy. In principle, such a sorting of superior/subordinate field boundaries could be applied more generally to entire field systems to identify the relative chronological successions of field boundaries.

The potential for applying this method on a field system in its entirety is first and foremost that it may offer detailed insight into its development and the principles behind it, including associated social processes, such as inheritance practices. A relative chronological sorting based on the $\mathrm{T}$-intersection principle will, however, rely on assumptions and entail uncertainties. First, the chronological consequence can only be assumed to be a dominant principle and not universally valid. A number of situations may give rise to the $\mathrm{T}$ morphology without the expected chronological sequence, for example if a straight boundary originally ending in a right angle is extended (Brück et al., 2003). Second, even well-preserved field systems are somewhat fragmented and have undergone modifications during their use (Becker, 1972; Nielsen \& Dalsgaard, 2017), which has implications for both the identification of the individual intersections and the reconstruction and sorting of the overall network.

The following article presents a method for analysing the hierarchical sorting of field systems based on T-intersections, and its application to three Danish Celtic fields. The analyses are based on a dataset for each field system that comprises a formal description of the relations between 
all intersecting boundaries. A stochastic optimization algorithm is used for the analysis, which allows the ambiguities and fragmentation in the dataset to be integrated in the formal analysis. The results of the analyses are discussed with respect to the possible implications for the understanding of principles of layout, agricultural strategies, and inheritance divisions.

\section{Organizational Principles and Dynamics of Celtic Fields}

The term 'Celtic fields' is used for a special type of field system that was common in large parts of north-western Europe primarily in the period $800 \mathrm{BC}-\mathrm{AD}$ 200, that is in the Nordic Late Bronze and Early Iron Age (e.g. Hatt, 1949; Brongers, 1976; Klamm, 1993; Lang, 1994). The mesh-like pattern of field boundaries-in the form of lynchets and low earthen or stony banks that enclose the individual fields-makes Celtic fields particularly suitable and interesting for studies of the layout and internal development of field systems. The layout of Celtic fields varies from structured field systems with many right-angled fields to 'aggregate' field systems that, because their fields are irregular, appear to have developed in a more organic way (Bradley, 1978; Lang, 1994; Nielsen \& Clemmensen, 2010). A certain degree of dynamics within the field systems, involving addition of new boundaries and temporary or permanent discontinuation, removal, or relocation of old boundaries, has been documented at several sites (Becker, 1972; Nielsen, 1993; Nielsen \& Clemmensen, 2010; Nielsen \& Dalsgaard, 2017).

Based primarily on analogy to historic and modern field systems, there seems to be two basic organizing principles that have particularly influenced the layout and transformations of field systems: 1) agricultural strategies, and 2) marking of use rights and labour obligations (e.g. Widgren, 2006). In relation to agricultural strategies, the field system could, for instance, reflect and assist fallow and crop rotation by providing a material structuring of the rotation system with the possibility of keeping livestock and crops separate, as well as by dividing the landscape into uniformly yielding entities that could ensure stable yields from year to year despite the rotation. It has also been suggested that subdividing boundaries were used for separating areas with different crops (Sørensen, 1973: 346; Brongers, 1976: 60), just as some fields may have been intended for other purposes, such as grazing (Pryor, 1998). Field boundaries could also be used to mark rights and labour obligations in relation to particular areas. Thus, the boundaries could represent markers of communal and more individual rights at different levels, depending on the existing practices of land ownership. For instance, subdividing boundaries could have been a way of structuring the division of larger pieces of enclosed land among local farmsteads (Veibæk, 1974; Donat, 1992; Nielsen \& Clemmensen, 2010: 219). While such a distribution may have been part of the initial land allotment, the subdividing boundaries could also reflect divisions that had taken place over time as part of inheritance practices (Hatt, 1939) or in relation to the establishment of new households (Holst, 2010). If land was divided among a number of households, one would expect to see boundaries that divided the area either equally or in fixed ratios according to the existing practices of land allotment or inheritance. Fields divided in ratios of 1:1, 2:1, and 3:1 have been identified at several Celtic fields throughout northwestern Europe (e.g. Hatt, 1949: 129; Müller-Wille, 1965: 50; Lindquist, 1974: 25; Nielsen \& Clemmensen, 2010: 220). 
In addition to the two main organizational principles (i.e. related to agricultural strategies and marking of use rights and labour obligations), there is an obvious consideration of the physical landscape in the structure of most field systems. Both slopes and drainage can influence the limits of the overall field systems as well as the shape and layout of individual field plots (see maps in Hatt, 1949). Furthermore, pre-existing structures in the landscape such as barrows, clearance cairns, trackways, or large boulders have sometimes influenced the course of individual boundaries (Hatt, 1949; Brongers, 1976: 57; Bradley, 1978: 268; Nielsen \& Clemmensen, 2010: 206). It has been suggested that the individual plots of the Celtic fields reflect the size of a suitable working unit, for example corresponding to the area that could be tilled by ard in a day (Fowler, 1967: 24; Lindquist, 1974: 29; Nielsen, 1993: 115). However, although the fields are generally small $\left(<3000 \mathrm{~m}^{2}\right)$, the sizes of the fields vary within and between different field systems, and in the well-preserved field systems it is evident from the morphology and stratigraphy that small fields have sometimes formed through divisions of larger fields (Müller-Wille, 1965; Nielsen, 2000: 184; Nielsen \& Dalsgaard,
2017). Their size, therefore, need not be attributed to a single factor.

\section{Methods}

As noted above, the morphology of the intersection of field boundaries may form the basis for an identification of relative chronological sequences or hierarchical principles in the layout of field systems. This is based on the assumption that $\mathrm{T}$-intersections of field boundaries provide indications of subordinate structures, which can be formalized into a relational expression.

In this study, the translation of the field system was conducted by first breaking down the field boundaries into line segments defined by intersections or angular breaks $\left(>30^{\circ}\right)$ in the course of the boundaries. These line segments constitute the entities of the analysis and are assigned a unique ID number. The intersections of the lines are then used to define relations of equivalence $(=)$ and subordination $(<)$ between the lines according to the principles outlined in Figure 1. The process of moving from the digitized field boundaries represented by line segments to a relational description of these intersecting lines is shown in Figure $2 \mathrm{a}$ and $2 \mathrm{~b}$.
Intersection type:

Line segment definition:

Relations:

\section{T-intersection}

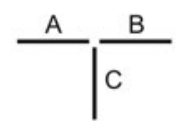

$A=B \wedge A>C$

\section{+-intersection}

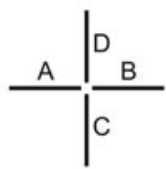

$A=B \wedge C=D$ angle

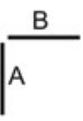

$A=B$

Figure 1. The principles used for translating the course of the field boundaries into relational expressions. The boundaries are split into line segments based on intersections and angular breaks in the course of the boundaries. The line segments are related to each other by the symmetric relation of equality (=) and the asymmetric relation of subordinate/superior $(>/<)$. The symbol $\Lambda$ denotes the truth-functional operator 'and'. In +-intersections, it is assumed that line segments making up continuous boundaries are contemporary but that the two continuous boundaries are not (without being able to say which is oldest). This relation is described by an 'exclusive or'-disjunction $(\oplus)$. 


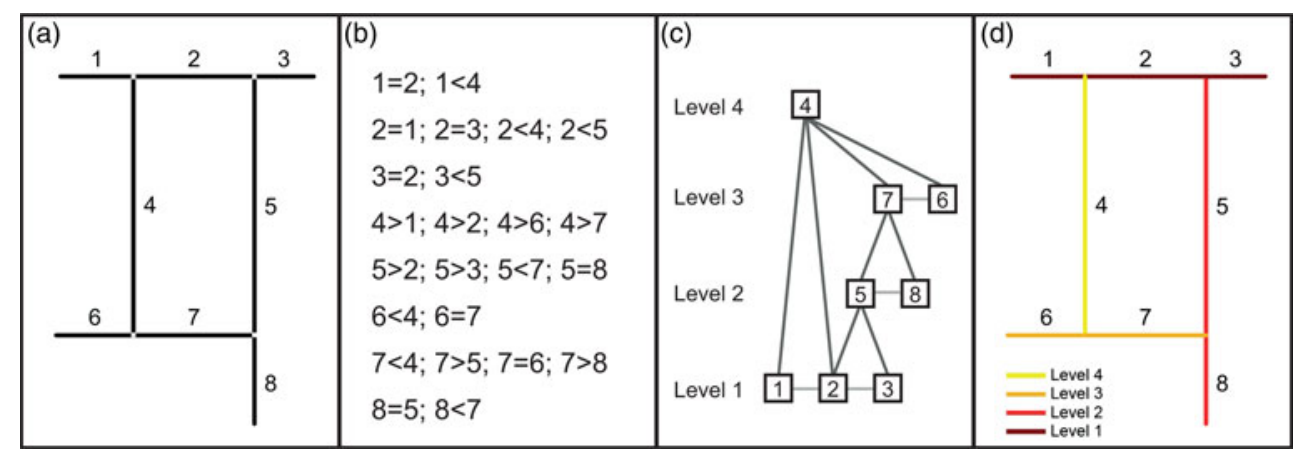

Figure 2. The processes involved in the relative chronological analysis: (a) the field system is digitized and each line segment is given a unique ID number; (b) the relations between all intersecting boundaries are described; (c) the data analysis is conducted in Tempo, resulting in a graph where the field boundaries are sorted into a number of hierarchical/relative chronological levels (here simplified and redrawn); (d) the final sort is mapped in a GIS program. When dealing with complex datasets of entire field systems, a number of unfulfilled relations will usually be present (and marked on the Tempo graph). This number can usually be reduced by manually rearranging the nodes (representing the field boundaries) in a process where the consequences are continuously being evaluated in the GIS program.

The formalized descriptions of the relations between intersecting field boundaries makes it possible to represent the field systems as a relational structure defined from a direct graph (possibly cyclic), where the presence of disjunctions gives rise to a family of different directed graphs. The representation is, thus, analogous to the relational representation of stratigraphy as a directed acyclic graph (DAG) used as basis for Harris Matrix analyses (Harris, 1975; Herzog, 1993).

A relational structure allows us to sort the entities based on their directed relations. In the Harris Matrix analysis, all relations must be unambiguous and logically consistent, leading to a DAG structure; and an optimal partial ordering can, therefore, be identified with topological sorting (Knuth, 1997). However, in the analysis of field systems, such logical consistency cannot be assumed. This is first of all due to the dynamics of the field systems, where fields can be added as well as removed, and, second, because the underlying assumption behind the sorting process, that is that $\mathrm{T}$-intersections represent a relative chronological order, can only be considered a dominating principle and may not always be valid. Thus, $\mathrm{T}$-intersections (and +-intersections) could also result from extensions of straight boundaries. Furthermore, uncertainties come with irregular intersections that are difficult to interpret (Figure 3).

When analysing field systems, conflicting relations must, therefore, be allowed for in the sorting; instead of calculating a single logically true solution, it becomes a question of obtaining and evaluating various plausible sortings, where as many of the relations are fulfilled as possible.

Formally, let $E$ be the space of possible solutions such that an element $e \in E$ corresponds to a given relative chronological ordering. Let $f: E \rightarrow \mathbb{N}_{0}$ be the objective function, which counts the number of unfulfilled relations; the lower the objective value, the more consistent the relative chronological ordering will be with the available relational information. Accordingly, a solution with an objective function value of zero implies that all relations are fulfilled in the chronological ordering. The aim of the analysis is to solve the optimization problem $e_{0}=\operatorname{argmin}_{e \in E} f(e)$. 


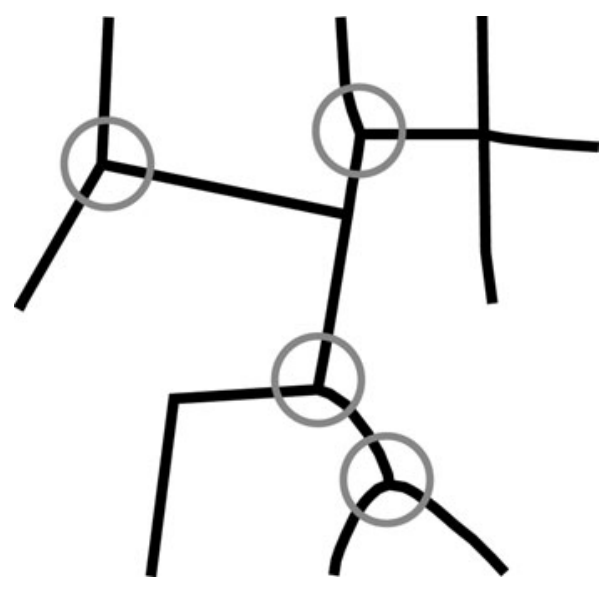

Figure 3. Examples of intersections at the Celtic fields of Skorbak Hede, where it can be difficult to decide how to describe the relations.

The size of the solution space grows exponentially with the number of vertices in the graph, which excludes exhaustive searching for moderate size problems. Further, no algorithm which runs in polynomial-time is known for finding the global minimum for this problem. We emphasize that this is a consequence of the introduction of the unambiguous relations. However, stochastic optimization has been successfully applied for similar graph theoretic problems and the particular problem described here (Aarts et al., 1988; Sharon, 1995; Holst, 2004). The basic idea is to avoid exhaustively searching the solution space $E$ by instead randomly sampling from it. With a well-designed sampling procedure, such algorithms can produce solutions of high quality with limited computation time, albeit without guarantee that a global minimum is obtained.

In this project, a stochastic optimization algorithm called 'simulated annealing' (SA) (Kirkpatrick et al., 1983), implemented in the computer program Tempo, has been used for the analysis (Holst \& Holst, 2004). ${ }^{1}$ The sort obtained through the Tempo

1 Tempo is a further development of the Posar program developed by Sharon (1995). analysis is presented as an ordered graph with the vertical axis representing the directed ordering of the entities, that is, a temporal progression from bottom to top in a relative chronological analysis or hierarchical levels of dependence in datasets with relations of subordination. In the analysis of field systems where the individual field boundaries constitute the entities, the 'oldest' boundaries will appear in the bottom of the graph, the 'youngest' in the top (Figure 2c).

The SA algorithm works by iterating over the steps described below. From a given solution $e[n]$, a new solution, $e^{\prime}$, is obtained by randomly swapping the relative chronological ordering (position in the graph) of two vertices. If $f\left(e^{\prime}\right) \leq f(e)$, the solution is accepted and we set $e_{n+1}:=e^{\prime}$. If $f\left(e^{\prime}\right)>f(e)$, the new solution is still accepted with probability $p=\exp \left(-\left(f\left(e^{\prime}\right)-f(e)\right) / T_{n}\right)$. The series $\left(T_{n}\right)_{n \in \mathbb{N}}$ is the 'cooling schedule' and must be designed so that it goes slowly towards zero, that is so that the probability of accepting a worse solution goes slowly towards zero as the number of iterations increases. This property allows the optimization sometimes to go uphill, thereby reducing the risk of getting stuck at a local minimum. Initial solutions can be obtained by random ordering or from a topological sort by ignoring disjunctions. The algorithm terminates after a fixed number of iterations or when the objective function reaches zero. Under regularity conditions, the SA algorithm converges to an optimal solution (Hajek, 1988); however, some manual tuning of the optimization parameters is often necessary for optimal results. Furthermore, when dealing with complex relational structures such as field systems, the Tempo analysis should only be considered an initial step in the sorting, which cannot stand alone. In order to reach a sort which has the lowest number of unfulfilled relations as possible, and which makes sense based on our understanding of the field system, 
topography, etc., it is necessary to conduct manually an exploratory evaluation of the relative chronological sort. This is done by a discursive process of testing the flexibility and consequences of rearrangements of the position of the individual line segments within the Tempo graph and mapping different levels of the graphs in a GIS program (Figure 2d). The results are evaluated in relation to a prior understanding of the degree of uncertainty of the relations and what constitutes meaningful overall structures, which results in a final choice within the scope of possibilities within the lowest objective value. For instance, it may be relevant to ignore the relative chronological level of certain boundaries if these do not seem to have evolved by following the $\mathrm{T}$-intersection principle. Thus, although there may exist a range of formally equally valid solutions (i.e. solutions with the lowest possible number of unfulfilled relations), the final result is reached on the basis of well-considered choices. The final result should, however, only be considered a selected model of the relative chronological development of the field system, which nevertheless may provide valuable insight into the possible principles behind the layout.

\section{Case Studies: Three Danish Celtic FIELDS}

In this study, three of the largest and bestdocumented Celtic fields in Jutland, Denmark, are analysed: Byrsted Hede, Skørbæk Hede, and Øster Lem Hede (Figure 4) (Hatt, 1938, 1949). The three

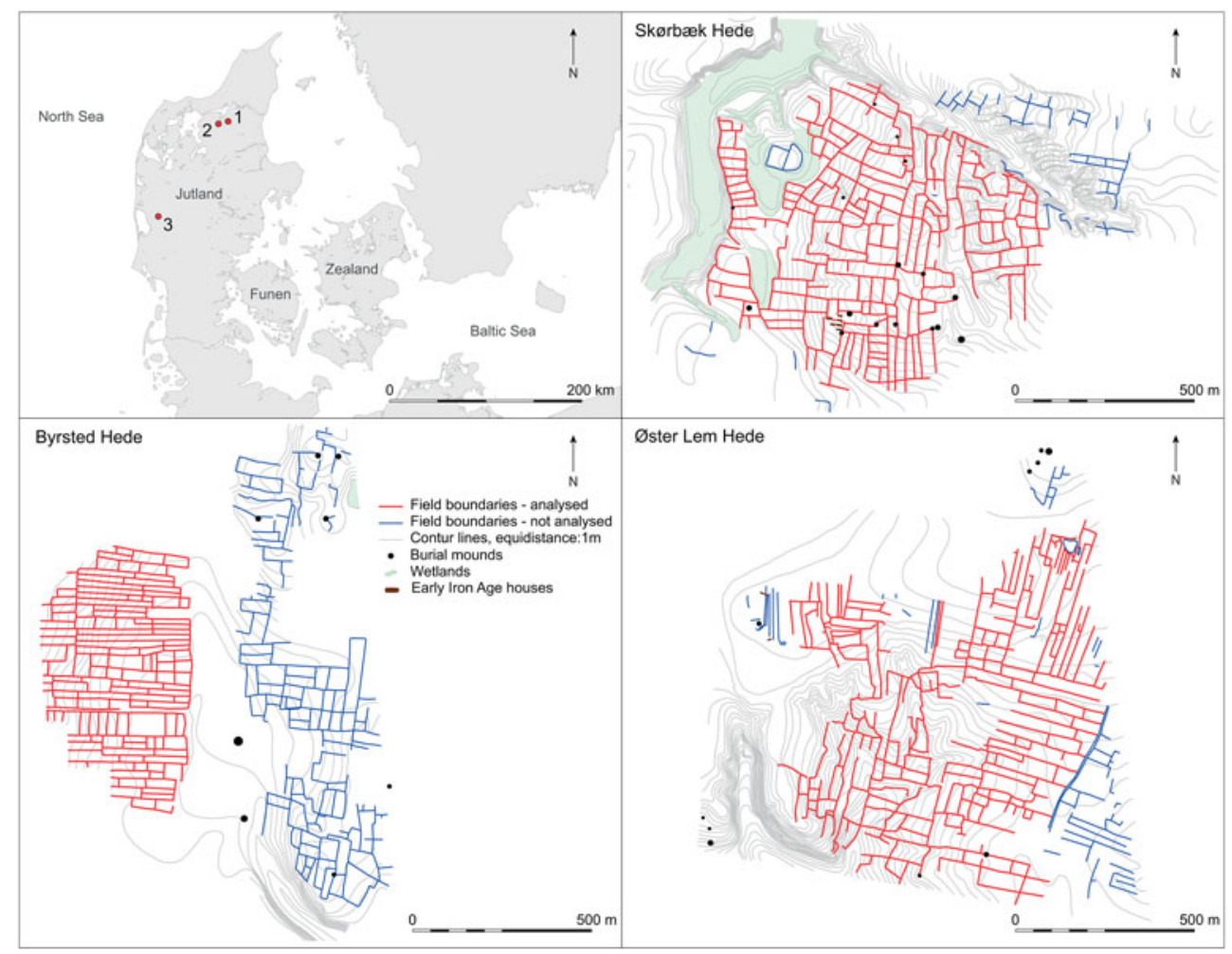

Figure 4. Location and layout of the three analysed Danish Celtic field systems, Byrsted Hede, Skorbak Hede, and Øster Lem Hede. The maps of the field systems are based on Hatt, 1949. 
sites were chosen among the more structured Celtic field systems because the relations between the field boundaries in these are easier to describe and thereby analyse; problematic intersections (see Figure 3) were limited to $14 / 258$ intersections at Skørbæk, 8//248 at Øster Lem, and 0/213 at Byrsted Hede. However, this also means that the results of the relative chronological analyses cannot be considered representative for all Celtic fields.

Byrsted, Skørbæk, and Øster Lem Hede are all located in a partly undulating terrain and the field boundaries, therefore, appear as banks as well as lynchets. At Skørbæk Hede, the topographical setting of the field system has clearly influenced the layout since steep slopes and wetland, e.g. towards the north and in the western part, represented natural boundaries that could not be ignored (Figure 4). Each of the field systems originally covered more than 100 ha, but today only $\varnothing$ ster Lem Hede is preserved to a greater extent within a protected heath (Figure 5). They are all situated on sandy soils with relatively low nutrient contents and with expectedly long regeneration times; even in historic times, when manuring was more intensive, such sandy soils needed several years of lying fallow after a period of cultivation (Frandsen, 1988). The land-use strategies must, therefore, have involved a kind of rotation system with fallow periods.

In Figure 4, the field boundaries that were included in the relative chronological analysis are marked in red. Isolated smaller areas or individual field boundaries were not included in the analyses. Furthermore, it was decided to focus on the separate,
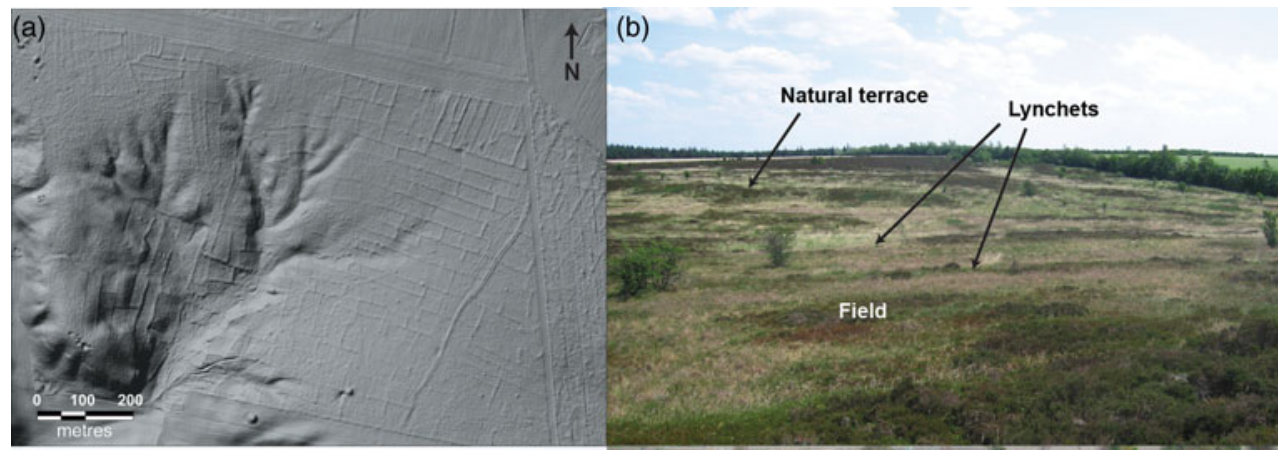

(c)

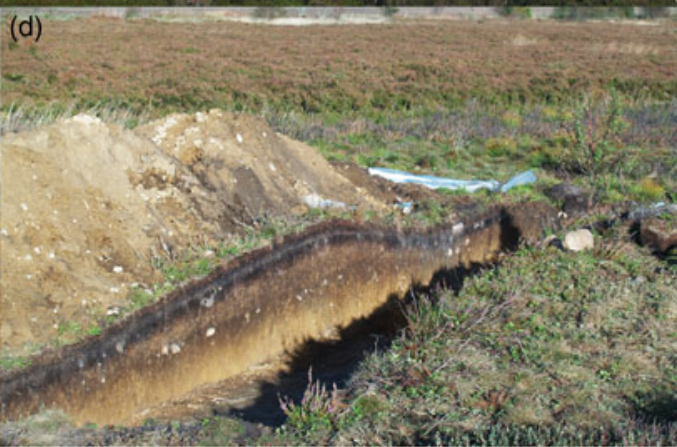

Figure 5. The field system at Øster Lem Hede, Denmark. (a) LiDAR map of Øster Lem Hede; (b) lynchets and a natural terrace in the southern part of the heath; (c) heather-clad banks in the eastern part of the field system; (d) section through a bank. Figure 5a: (C) Geodatastyrelsen. Other photographs: N.H. Nielsen. 
western part of Byrsted only, as this is where the largest and most coherent parts of the field system are found. Since the westernmost field system at Byrsted consists of two separate parts, a Tempo analysis was conducted on each of these, Byrsted South and Byrsted North.

\section{Results}

Tempo produces a sorted sequence of the boundaries based on assumed relative chronologically significant intersections. Consequently, the results can be considered a proxy for a relative chronological sequence or, alternatively, a form of hierarchical organizational structure in the definition of the field systems (see supplementary material for MapInfo and Tempo files of each field system).

Apart from the analysis of Byrsted South, which reached a score of zero, the Tempo analyses produced results with seven, nine and fifteen unfulfilled relations at Øster Lem, Byrsted North, and Skørbæk respectively. The actual score in Tempo is twice as much because the relations between the entities appear twice in the descriptions (the relation and its inverse relation, e.g. $A=B$ and $B=A$ ). The unfulfilled relations are concentrated on four to ten intersections within the three field systems (Figure 6). Bearing in mind the complexity of the layout and the total number of relations (Byrsted South: 405; Byrsted North: 883; Skørbæk: 1616; and Øster Lem: 1589), the scores must be considered low.

In Figure 6, the results of the Tempo analyses of the three field systems are presented with colours representing the different relative chronological horizons (levels) in the analysis. As described in the methods section, the final Tempo result of each field system represents one model, chosen from several others based on a manual exploration where the strength and ambiguities of the position of the individual field boundaries have been assessed. The chosen model was then used as the basis for an interpretative evaluation of the development and organization of the field system, bearing in mind that it does not provide an exact account of the formation of the field system.

The three field systems exhibit significant variation but also several common features. In all three systems, the relative chronologically oldest lines form large and relatively regular structures delimiting major blocks or strips of land separated by open space. A relative chronologically secondary set of structures extend these blocks or divide them into series of relatively even-sized major parcels, often in the form of band-structures with a comparable width. These parcels are then further divided either in a structured way (by straight boundaries laid out perpendicularly to the boundaries of the major parcels) or more randomly. In the Tempo analysis, these boundaries are a composite of relative chronological horizons, which reflect both the fact that subdivisions have been a recurring phenomenon and that subdivisions constitute a nested hierarchical structure, where the relative chronological level depends on the levels of the overall parcels it subdivides. Finally, there is a group of small-scale field demarcations that seem to have been added onto the primary overall blocks of land or were built to fill out the space between primary demarcations. As with the subdivisions, these additions are represented on many relative chronological levels. In this way, the development of the field systems can be described as following five overall principles (Table 1).

Particularly at Øster Lem and Skørbæk Hede, the major parcels appear as interrupted structures, which is best explained by the development of the system involving the removal of earlier boundaries in addition to 


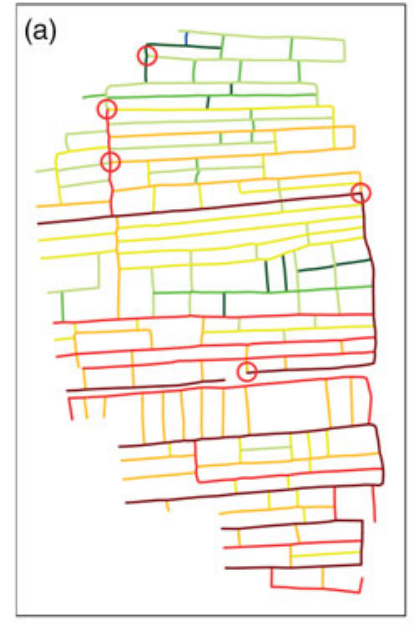

$200 \mathrm{~m}$

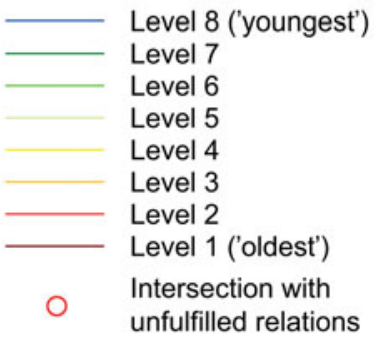

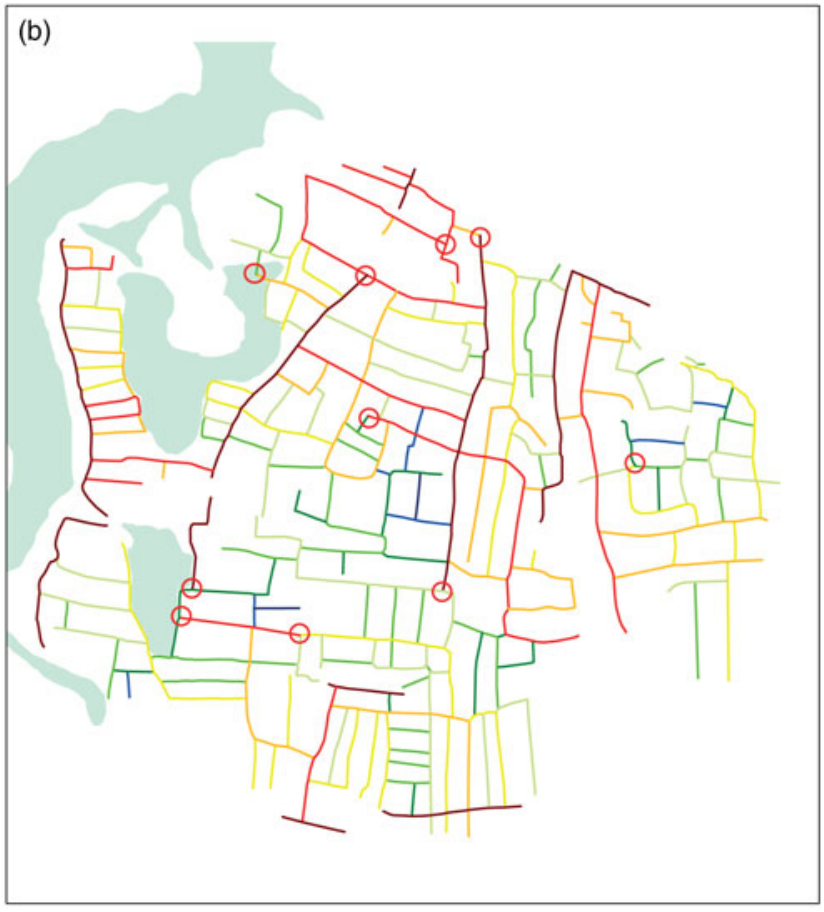

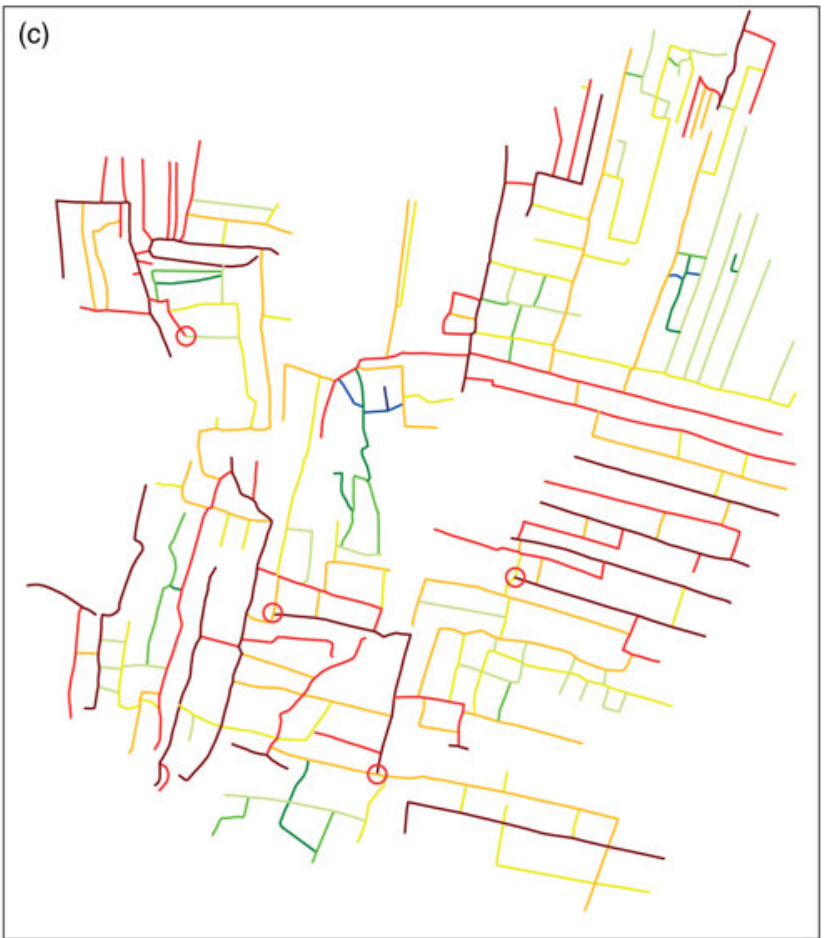

Figure 6. Maps showing the results of the relative chronological analyses of (a) Byrsted Hede, (b) Skorbak Hede, and (c) Øster Lem Hede. Boundaries whose exact position in the relative chronology is not known (e.g. where a boundary is only intersecting at one point) have been placed at the oldest possible level. 
Table 1. The main principles identified in the development and organization of the Celtic fields.

1) Establishment of primary boundaries and structures defining and marking larger blocks of land

2) Creation of medium sized areas - major parcels a. by subdividing the primary structures

b. by adding new regular areas to the existing structures

3) Subdivision of major parcels into smaller fields in the form of structured partitioning (including secondary modifications following a regular pattern)

4) Subdivision of major parcels into smaller fields in the form of unstructured partitioning (including secondary, irregular modification)

5) Addition of new fields/blocks of fields deviating from the original principles

a. by adding fields outside the original layout

b. by infilling areas between existing, separate parts of the field system

the extension and subdivisions. At Øster Lem Hede, the practice of adding and discontinuing boundaries has in fact been documented during excavations (Nielsen \& Dalsgaard, 2017). It would have been desirable to sort out the redefinitions of boundaries as a separate phenomenon, but it was considered too uncertain to do so. Especially with regard to the irregular subdivision of major parcels into fields, it is difficult to distinguish between fields that are part of the primary layout and fields that have come about through later modifications. In the following discussion of the individual field systems, the Tempo results belonging to each principle have been illustrated on separate maps (Figures 7, 9, and 10).

\section{Byrsted Hede}

At Byrsted, the chronologically oldest boundaries nicely demarcate three primary structures, the largest (whose original extent to the west is not known) extending around 10 ha (Figure 7a). These structures have subsequently been subdivided into major parcels in the shape of elongated bands, c. $30 \mathrm{~m}$ wide. Moreover, bands have been added successively on to the primary structures, as seen for example from the sequence of an orange, yellow and light green coloured bands added on to each other in the northern part of Byrsted (Figure 7b). The major parcels generally cover areas of $0.8-1.5$ ha. In the very structured layout of Byrsted, it cannot be ruled out that parts of the primary structures developed through successive additions of bands whose easternmost boundaries were just aligned. This, however, cannot be determined since the field system no longer exists.

The subdivision of the major parcels is almost entirely carried out in a standardized way (according to principle 3) where bands generally have been divided first longitudinally and then crosswise (Figure 7c). Crosswise divisions are, however, dominant in some instances, for example in the northern part of Byrsted South and Byrsted North. The different ways of dividing the major parcels result in either elongated or broad fields, which may reflect different functions or preferences that could have varied over time or between users.

Some bands include elongated as well as broad fields. These may be a result of secondary modifications, where for example selected field boundaries were removed to make broad fields. Due to the regularity of the field boundaries, however, it is difficult to decide with any certainty. Secondary divisions are nevertheless clearly represented by the boundaries that divide approximately similar-sized fields into even smaller fields (e.g. the easternmost level 7 boundary in the central part of Byrsted dominated by green boundaries, Figure 7c) or the few irregular field boundaries overruling the strict layout (Figure 7d). Only a few fields or blocks of fields have been added onto the primary 

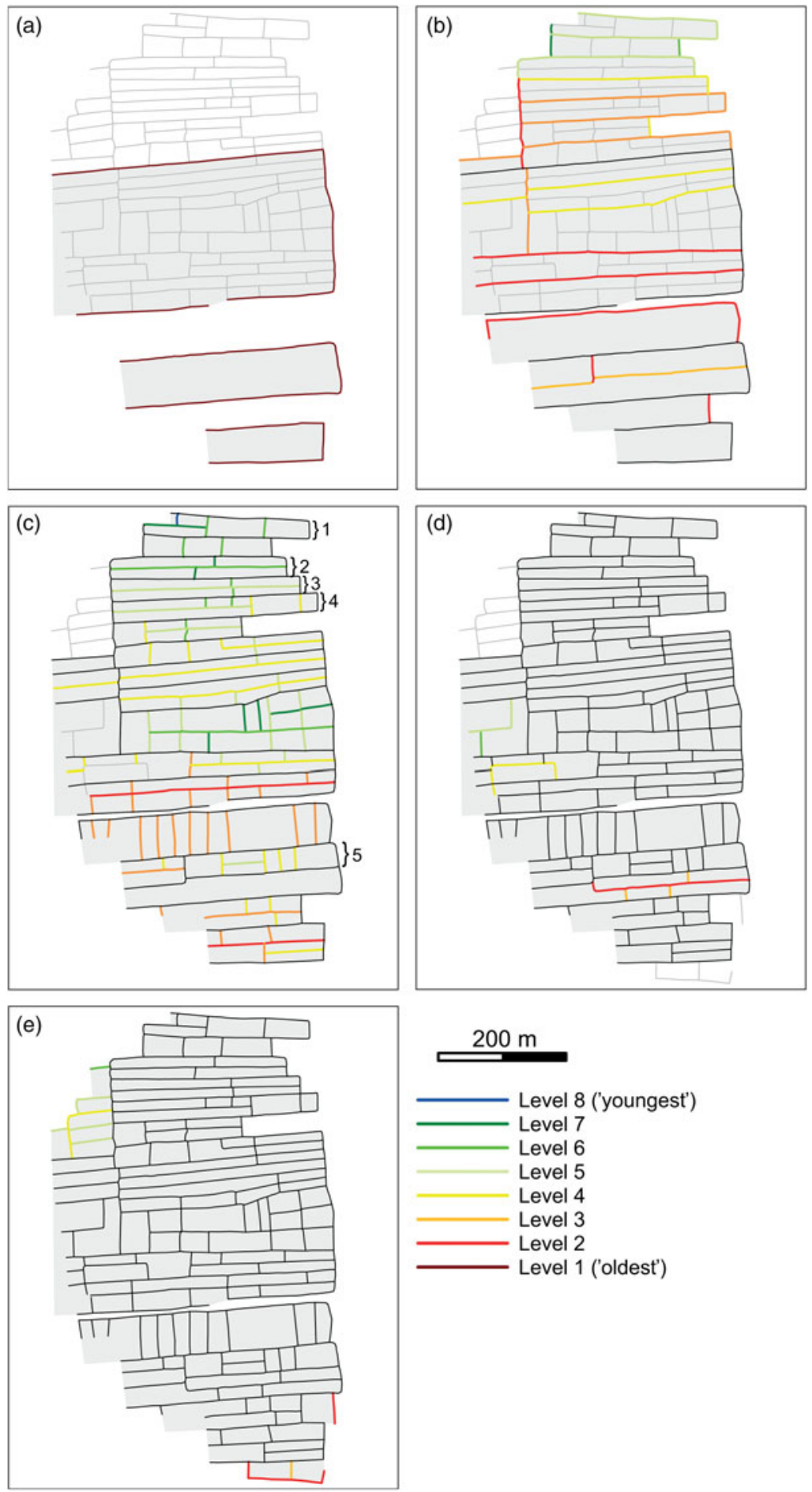

Figure 7. Maps showing the Tempo results of Byrsted split into different principles governing the layout (see Table 1 for definition of the principles). (a) principle 1; (b) principle 2; (c) principle 3; (d) principle 4; (e) principle 5. The numbers in (c) refer to the major parcels whose subdivision is illustrated in Figure 8. 
1)

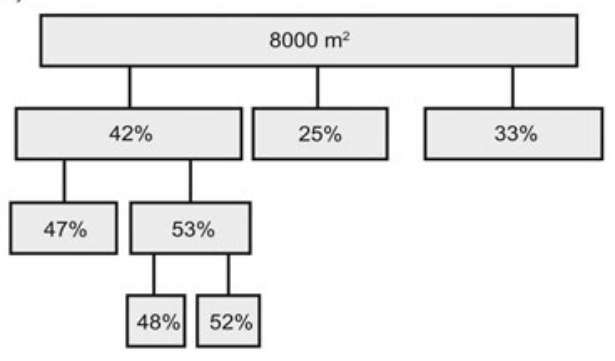

2)

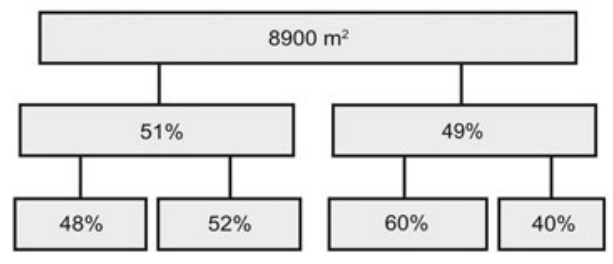

3)

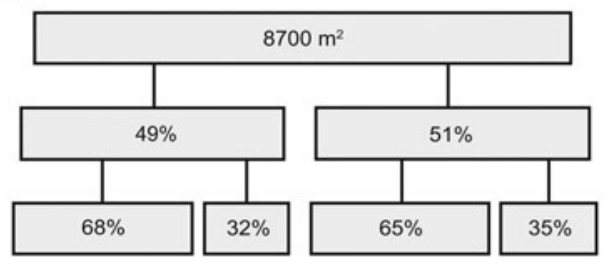

4)

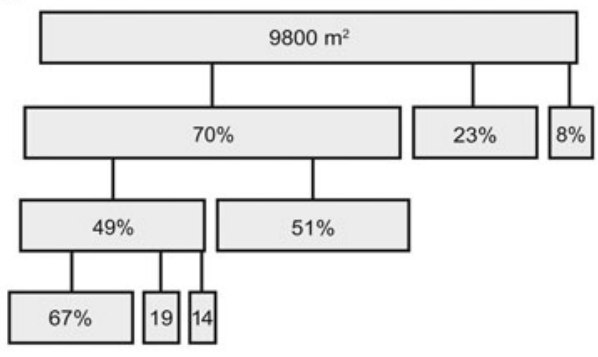

5)

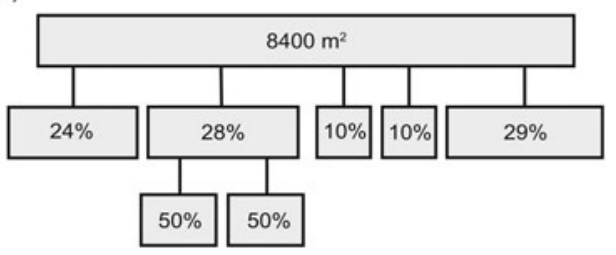

Figure 8. Diagrams showing the way five selected bands of Byrsted have been subdivided. The total size of the major parcels is listed in the top bars, while the subdivisions in percentages are shown in the bars below. The layout of the selected major parcels can be seen in Figure 7. part of the field system at Byrsted (Figure 7e).

The sizes of the fields at Byrsted vary, but the bands and smaller areas have often been divided in a certain way, either to form similar sized fields within the area, or to form fields with a fixed size ratio. The diagrams in Figure 8 show how five selected bands from Byrsted have been subdivided. What is striking is the prevalence of quite accurate divisions of the land into halves (Figure 8: 1-5) and two thirds (Figure 8: 1, 3, 4), although other divisions are present as well.

\section{Skørbæk Hede}

At Skørbæk, several of the oldest boundaries demarcate larger primary structures (up to $10 \mathrm{ha}$ ), but the complexity and modifications of the layout indicate that not all 'old' boundaries, marked in brown and red on Figure 9a, necessarily represent the oldest levels (e.g. the brown N-S running boundary in the eastern part of the field system).

Major parcels are first of all formed by subdividing the large, central primary structure into smaller units (Figure 9b). Furthermore, major parcels have successively been laid out in the southern part of the field system, which in this way expanded northward as well as westward, even across the southernmost wetland. The boundaries of the major parcels are not completely defined, but the sizes of the major parcels at Skørbæk measure $c$. 0.4-2 ha.

The major parcels at Skørbæk are subdivided by field boundaries laid out in a structured as well as unstructured way. In the southern part of Skørbæk, especially, the major parcels have been divided in a very structured way and often with the aim of obtaining similar sized fields through bisections or sometimes 

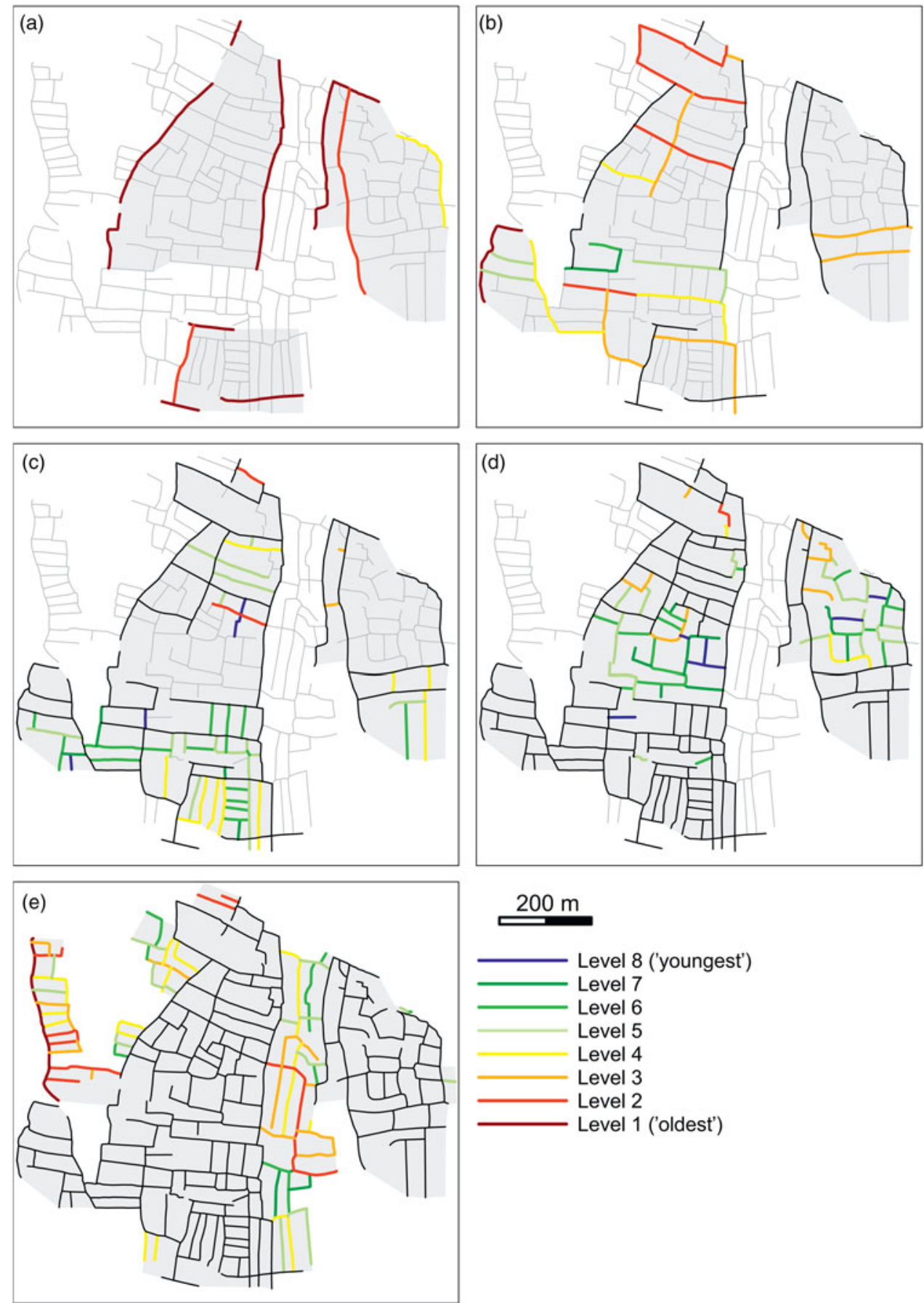

Figure 9. Results of the relative chronological analysis of Skorbak Hede split into different principles governing the layout (see Table 1 for definition of the principles). (a) principle 1; (b) principle 2; (c) principle 3; (d) principle 4; (e) principle 5. 

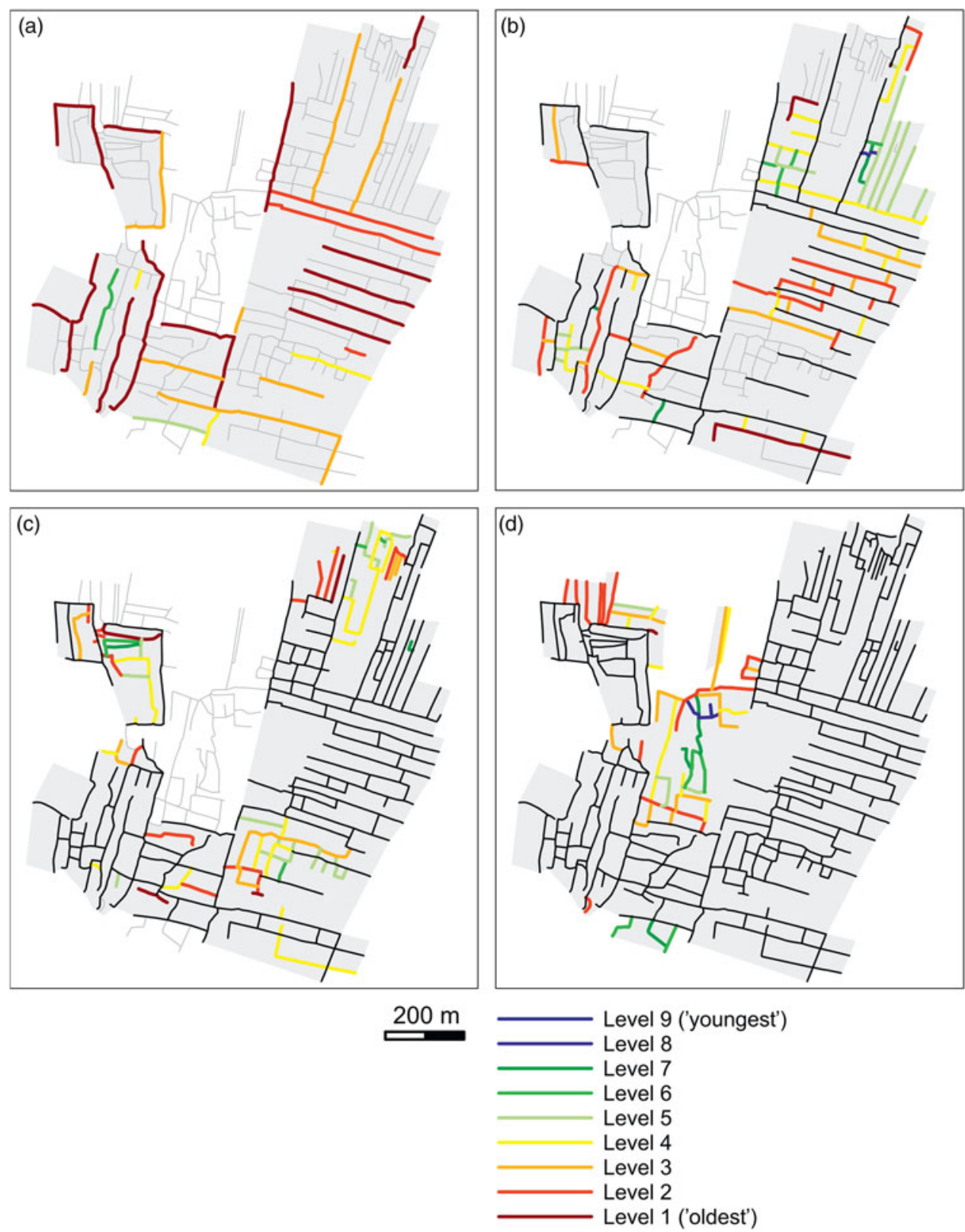

Figure 10. Results of the relative chronological analysis of Øster Lem Hede split into different principles governing the layout (see Table 1 for definition of the principles). (a) principle 1 and 2; (b) principle 3; (c) principle 4; (d) principle 5.

trisections (Figure 9c). In the central primary structure, remnants of structured subdividing field boundaries, as well as boundaries established in a more ad boc manner, are present (Figure 9d). In addition, a few examples of secondary modifications can be identified, for example the curved part of the orange boundary in the very centre, which seems to ignore the original layout. The 
orientation of the fields appears to indicate that, at some point, the northern and southern part of the field system developed into one; and, particularly where these parts meet, fields are less regular and sometimes partly modified.

The division of the eastern primary structure was probably initially also divided in a rather structured way, which is indicated by the north-south running boundaries. Today, however, the boundaries are no longer aligned and this part of the field system has a more organic appearance, which may be due to secondary modifications.

At Skørbæk, fields were added to the existing layout in different ways (Figure 9e). First of all, the field system expanded into the wetter area towards the west by establishing fields on both sides of the northernmost wetland. Generally, these fields seem to have been laid out one to three at a time. While their internal relative chronology is very clear, their chronological relationship with the main part of the field system is not, as they are only connected to this by a single boundary. However, it seems reasonable to assume that the fields to the far west, with a marginal position and poorer accessibility, were brought into cultivation in a late phase, when other possibilities of expanding the field system were limited. Secondly, the area between the central and eastern primary structure was filled with successively added fields or blocks of fields, which meant that the two originally separate parts of the field system eventually developed into one system.

The southernmost added fields marked in yellow and green were subdivided in a similar way as the southernmost major parcel, and may well be chronologically closely related to this. The units measure approximately 0.5 ha and have been divided lengthwise. Further, in other parts of Skørbæk, fields have been subdivided into smaller, equally sized fields, although these have no consistent size. It does, however, seem far-fetched to try to correlate the subdivided fields with the number of farms (three to four) found at Skørbæk as has previously been attempted (Steensberg, 1951: 196; Nielsen \& Clemmensen, 2010: 219), especially since the houses are from the late Pre-Roman Iron Age and Early Roman Iron Age and, therefore, presumably from a late phase of the field system, by which time the fields were already subdivided.

\section{Øster Lem Hede}

At Øster Lem Hede, it seems that an almost $1 \mathrm{~km}$-long, straight boundary originally ran approximately NNE/N-SSW/S across the landscape and terminated in a burial mound (the southernmost burial mound in Figure 4). Today, the central part of this boundary is missing, probably due to later turf cutting in the area (Figure 10a). This boundary presumably represents one of the oldest primary boundaries that divided the landscape into sections that were subsequently divided into major parcels and fields. The northernmost east-west running boundary that separates the parts of the field system with differently orientated fields may represent another primary boundary. Otherwise, it is not possible to separate the boundaries reflecting principle 1 and principle 2 at $\varnothing$ ster Lem Hede due to the fragmentation of the field system. Thus, the boundaries that are only weakly connected to the rest of the field system come out as old boundaries in the Tempo analysis, although they seem to represent principle 2 (Figure 10a). The regularity and parallelism of the boundaries nevertheless indicates remnants of narrow elongated bands similar to those present at Byrsted. In addition to these bands, wider rectangular major parcels of 
up to 2 ha were laid out, as for example in the southern-central part of the field system. Interestingly, the major parcels were here laid out while completely ignoring the large steep natural terrace depicted on Figure $5 \mathrm{~b}$ (and marked by the oblique red line in Figure 10b).

At Øster Lem Hede, it is not possible to identify a clear chronological development among the major parcels. Nevertheless, a certain regularity in the width of the eastwest orientated bands can be seen: the four southernmost bands are $c .50 \mathrm{~m}$ wide, and the three northernmost bands $c .70 \mathrm{~m}$ wide. This may indicate that bands of a similar size are chronologically quite close to each other, while there is a gap in time between bands of different widths. Alternatively, the difference could be explained by the fields having been laid out by different families or social groups.

The regular major parcels at Øster Lem Hede have generally been subdivided in a structured way. For example, the bands are often first divided longitudinally (Figure 10b). Other major parcels at Øster Lem Hede comprise fields, which have been laid out in a less strict way as seen, for example, in the north-western part of the field system (Figure 10c). Furthermore, several of the boundaries shown in Figure 10c seem to represent secondary modifications, especially in the south-eastern and north-eastern sector where it is difficult to identify any clear pattern of subdivisions.

Additions to the original layout were also made at Øster Lem Hede (Figure 10d). In the central part, a few fields were added successively and probably fairly early on in the use of the field system since OSL dates show that this area was already cultivated in the Late Bronze Age (Nielsen \& Dalsgaard, 2017). North of these fields, the area between the western and eastern sectors was partially infilled with fields in a more unstructured way, probably partly because of the more undulating terrain.

\section{Discussion}

The morphology of the three Celtic fields analysed here varies considerably: Byrsted is very structured, while Skørbæk and to some degree Øster Lem Hede have a more organic appearance in places. Yet, despite the morphological differences, it has been possible to identify five overall principles that are represented to different degrees in each of the field systems. Below, we discuss the results of the relative chronological analyses and the principles identified as governing the layout; and we present our interpretation of, among other things, the social implications.

\section{Principles 1 and 2}

Together, principles 1 and 2 constitute the basic formation of the Celtic fields. Principle 1 represents an initial parcellation of a landscape without indications of previous physical demarcations. These primary areas subsequently provide a framework for a number of further subdivisions. In the Late Bronze and Early Iron Ages, the organization of the individual farmsteads, which included stables in the longhouses for example, indicates that they operated as separate economic units (Webley, 2008: 21); and it has been suggested that a prehistoric household cultivated about 1-2 ha each year (Hagen, 1953: 100; Müller-Wille, 1979: 223; Pihl, 2013: 26). The size of the primary areas of up to 10 ha thus seems to exceed the operational scale of the small, basic households of the time, which suggests that the primary boundaries were established jointly by a community. The regularity in the primary structures varies between the 
analysed field systems, with Byrsted displaying the most regular structures and Skørbæk the most irregular. This difference is probably partly due to the more pronounced topographical features present within the area of Skørbæk Hede.

The boundaries laid out according to principle 2 defined some major parcels, generally measuring $0.4-2.5 \mathrm{ha}$, which can be compared to the rectangular, primary structures identified in Celtic fields in Vassen, the Netherlands (Brongers, 1976: 60) (c. 2 ha), and Bönde on Gotland, Sweden (Carlsson, 1979: 59) (0.8-1.3 ha). The major parcels were created either by subdividing the primary structures (principle 2a) or by enclosing previously unparcelled land (principle 2b). Both ways of creating these major parcels were used within the same fields system. At Byrsted, the major parcels defined by principle $2 \mathrm{a}$ and $2 \mathrm{~b}$ have the same morphology and size; this is not the case at Skørbæk, which is less regular.

Compared to the primary structures, the major parcels are more consistent in terms of size with the operations of individual households. Generally, several major parcels were defined within the individual primary block structures, and the sizes were equal to or less than the 1-2 ha assumed to have been cultivated by a household each year. Each farm must, therefore, have had access to several major parcels, depending on the size of the parcels, manuring practices, length of fallow periods, and household size. Consequently, the establishment of the major parcels could reflect either a process of dividing the primary blocks among the different households or an agricultural division of the land, such as in a fallow or crop rotation system. Different crops may also have been cultivated within the major parcels without this, leading to subdivisions. As the strip fields in Sweden make evident, smaller areas within large fields could be used for different purposes without being marked with physical boundaries (Widgren, 1990).

At the field systems, and especially at Skørbæk, there are clear indications of separate parts of the field system having been laid out by different groups or settlements. Thus, the field system appears to have developed through a growing together of the northern and southern (and eastern) sector, in which different principles of defining the major parcels were used. At Skørbæk and Byrsted Hede, there are, furthermore, several examples of major parcels that were added successively onto each other, indicating that the field system in these parts gradually expanded. A plausible explanation for this expansion would be demographic growth or gradual agglomeration of fields belonging to the local farmsteads. In continental northwestern Europe, farmsteads in the Bronze and earliest part of the Iron Age were dispersed in the landscape, but, in the late Pre-Roman Iron Age, small villages begin to emerge (e.g. Rindel, 1999; Roymans \& Gerritsen, 2002; Webley, 2008). The emergence of field systems could be considered an early phase of a general tendency towards agglomeration taking place in the first millennium BC: first the arable land became concentrated within certain defined areas, the field systems; later, the farmsteads also began to agglomerate in villages. Alternative explanations for the gradual expansion of the field systems could be an agricultural extensification of cultivation or competitive rationales.

At some point during the use of the field systems, a process of contraction may have taken place; but this is more difficult to identify as the physical boundaries of abandoned fields would remain in the landscape. Areas where a restructure overruled the earlier layout (e.g. indicated by boundaries of level 4-5, Figure 7d) could nevertheless represent land that had previously been abandoned. 
Clearly, the field systems-as represented by field boundaries laid out according to principles 1 and 2-were established by following certain principles, which generated a physical structuring of the landscape recognizable between different Celtic fields. Although the rights to the major parcels may have been held by individual households, they were part of larger communal structures. This is demonstrated by the settlement evidence, which clearly shows that the field systems were established across landscapes inhabited by numerous households and developed in a complex interplay with the dynamics of these settlements (Hatt, 1949; Becker, 1972). When new parcels were laid out, it must, therefore, have followed a degree of common principles of regulation across the different households. In this way, the joint establishment of the field systems had profound social implications by defining some basic and longlasting principles of rights of land and agricultural practices. The work involved in creating and maintaining the boundaries is also likely to have strengthened a collective identity and sense of community among the persons involved (e.g. Chadwick, 2008; Wickstead, 2008).

\section{Principles 3 and 4}

The subdivision of the major parcels has been conducted either in a structured (principle 3) or more unstructured way (principle 4). The Tempo analyses sometimes provide insight into the relative chronological sequence for the division of the major parcels, most clearly seen at Byrsted (Figures 7c and 8). Thus, although the subdivision could have been undertaken as part of a general, hierarchical principle, it seems likely that the subdividing field boundaries also reflect a temporal development, i.e. that they were formed later than the major parcels. This is especially evident from the more irregular fields at Skørbæk and Øster Lem Hede that appear to reflect a certain degree of restructuring of the field boundaries.

Although both the structured and the ad hoc subdivisions of the major parcels have been identified in each of the three field systems, the degree to which the two methods have been used varies considerably. The extremely regular layout of Byrsted seems to have had a self-regulating impact on later modifications as they were also carried out in a very structured way since all boundaries follow the orientation of the original layout. Apparently, the regular, physical structuring of the land left little room for secondary modifications overruling the existing syntactic structure. On the other hand, in the irregular field systems, the less distinct manifestation of the original principles of the layout did not provide the same guidance. Thus, the ongoing additions, eliminations, and repositioning of boundaries resulted in an even more ad hoc layout over time in these Celtic fields. Accordingly, the possibility of recognizing the original layout seems to depend on the time-depth of the field systems as well as the regularity of the initial parceling of the land. It can therefore be argued that it is in the regular field systems that the basic principles of the layout and the internal development are best recognized, although it may be difficult to separate out secondary modifications.

The regularity of the structured subdivisions is most clearly manifested in the proportionality of the areas emerging from the Byrsted subdivisions (Figure 8). Here, we see a very systematic devolution through the various stages based on divisions in halves and thirds. This form of proportionality indicates the presence of some underlying principles, which could include a form of systematic devolution of rights over time as, for instance, in a 
system of inheritance. In the much later Leges Barbarorum of the late first millennium $\mathrm{AD}$, the half and third part divisions are a recurring phenomenon connected with inheritance of rights to land (Murray, 1983). Particularly, the Edictum Rotharithe first written compilation of Langobard laws from $\mathrm{AD}$ 643-contains detailed descriptions of inheritance practices among the Langobards (Drew, 1973). What stands out in these descriptions is the systematic division of the land into fixed proportions depending on the number and status of the heirs. Two sons would generally inherit equal proportions of the land but, if one of them was born outside marriage (a 'natural' son), he would only receive one third, while the son born within marriage would inherit two thirds (Drew, 1973: 77, ch. 154). If two legitimate sons and one or more 'natural' sons were to inherit, the latter would only receive one fifth, while two fifths would be passed on to each of the two other sons and so on. Under certain circumstances, a daughter was able to inherit one third of the land, but generally women did not succeed unless there were no legitimate sons (Drew, 1973: 78). Although the interval between the Late Bronze/Pre-Roman Iron Age societies and that of the Langobards is long, the Edictum Rothari may offer an idea of the sort of principles potentially underlying the systematic divisions in the Celtic fields. Certainly, inheritance practices would seem to offer a convincing explanation. A division and redistribution of fields in relation to the establishment of new households is, however, also a possibility (Holst, 2010). Exactly what the different proportions might have reflected cannot be established, but the unequal divisions can be taken to indicate that people of different social status, age, and gender were entitled to different ratios. The alternative explanation, that the subdivisions were related to land-use strategies and a crop and/or fallow rotation, cannot account for the recurring phenomenon of subdivisions leading to a hierarchical breakdown of the individual fields in the same way. Even if there were an emphasis on particular crops, which would, therefore, be cultivated in larger areas, this cannot explain the ratios appearing in the field system. Divisions associated with a crop/fallow rotation would also be expected to be related to the size of the fields rather than ratios (apart from 1:1).

In the light of the relatively limited number of successive subdivisions, it is evident that the practice of subdividing the major parcels stopped after a few generations; it was not taken to the extremes seen in later societies with a bilateral kinship system, such as on the Faeroes Islands (Bjørk, 1957) and in the Swedish landscape of Dalarna (Sporrong, 1995). At this time, further divisions would probably have created fields whose small size would have made them less suitable for cultivation. However, after a few generations of following the practice of subdividing fields, the individual farmsteads must have held the rights to field plots lying scattered throughout the field system. Instead of dividing the fields any further in connection with inheritance, a certain number of field plots could, thus, be passed on to each of the heirs, just as new fields were perhaps laid out in order to avoid excessive subdivision (see also Holst, 2010). Furthermore, it is possible that fields that had been merged at some point, such as in relation to marriage, could be subdivided again at a later date, which may explain the combination of elongated and broad fields within a single band in Byrsted.

Although the Celtic fields at Skørbæk and Øster Lem Hede are more irregular compared to those of Byrsted, subdivisions according to fixed ratios can still be identified at these sites-especially divisions into halves or thirds-which may also reflect 
divisions associated with inheritance. In the very irregular areas, clear subdivisions, and thus indications of inheritance practices, are nevertheless difficult to recognize.

\section{Principle 5}

Principle 5 refers to fields that were added onto the pre-existing field system outside the initial large blocks and without defining major parcels. Thus, principle 5 seems to reflect small-scale expansions of the field systems that were undertaken generally without first defining a larger area. Presumably this took place when the original principle of enclosing land for cultivation could no longer be sustained, possibly due to lack of land within the primary structures. The fields have sometimes been bisected or trisected, but small fields laid out individually occur as well. These fields are likely to have been laid out by individual households at a time when small fields had become the norm.

The fields were laid out by using preexisting boundaries as base lines or by establishing fields further away, such as at the other side of the wetland in the western part of Skørbæk (principle 5a). New fields could also be added by filling in the area between two separate parts of the field system, as seen at Skørbæk especially and, to some degree, at Øster Lem Hede (principle $5 b$ ). By this means, originally separate field systems turned into a singular one, a practice also recorded in other Celtic fields (e.g. Brongers, 1976: 57).

Since the fields added according to principle 5 are external additions, it is only possible to conclude that they are later than the boundaries to which they are directly related; their relative chronological order compared to other parts of the field system cannot be determined. The close resemblance between some of the added fields and some of the structures within the originally defined layout (e.g. in the southern part of Skørbæk Hede) may, however, suggest that these were chronologically closely related.

\section{Conclusion}

To conclude, the Celtic fields analysed here appear to have been laid out according to certain syntactic principles that can be traced across the three field systems. The end-product-the layout that we see today - was the result of a development of the field systems over time that, in the interpretation presented here, is likely to have included a communal establishment of primary boundaries; the definition of major structures administered by individual farmsteads; successive subdivisions carried out in connection with inheritance; restructuring of the fields leading to an irregular layout in some places; the addition of new fields outside and between well-defined field systems (sometimes resulting in the merging of separate parts); and, finally, the post-abandonment demolition of boundaries. The regular Celtic fields that we analysed were not laid out according to a predefined plan, but they did evolve based on certain principles agreed upon by the farmsteads involved.

\section{Supplementary Material}

To view supplementary material for this article, please visit https://doi.org/10.1017/ eaa. 2017.56.

\section{ACKNOWLEDGements}

We would like to thank Lisa Gjelstrup Kristensen and Britt Maiken Hansen for participating in the initial phase of compiling the relations between intersecting field 
boundaries. Casper Skaaning Andersen is thanked for assisting with Figure 4, and Stephen Gadd for advice about English usage. Finally, we would like to thank Mette Løvschal and two anonymous reviewers for their useful comments and suggestions.

\section{REFERENCES}

Aarts, E.H.L., Korst, J.H.M. \& van Laarhoven, P.J.M. 1988. A Quantitative Analysis of the Simulated Annealing Algorithm: A Case Study for the Traveling Salesman Problem. Journal of Statistical Physics, 50: 187-206.

Becker, C.J. 1972. Früheisenzeitliche Dörfer bei Grøntoft, Westjütland. 3. Vorbericht: Die Ausgrabungen 1967-68. Acta Archaeologica, 42 (1971): 79-112.

Bjørk, E.A. 1957. Farosk bygderet. 1ste del: Husdyrbruget m.v. Fotografisk genoptryk af stencileret udgave. Torshavn: Matrikulstovan.

Bradley, R. 1978. Prehistoric Field Systems in Britain and North-West Europe: A Review of Some Recent Work. World Archaeology, 9: 265-80.

Brongers, J.A. 1976. Air Photography and Celtic Field Research in the Netherlands. Amersfoort: Rijksdienst voor het Oudheidkundig Bodemonderzoek.

Brück, J. 2000. Settlement, Landscape and Social Identity: The Early-Middle Bronze Age Transition in Wessex, Sussex and the Thames Valley. Oxford Journal of Archaeology, 19: 273-300.

Brück, J., Johnston, R. \& Wickstead, H. 2003: Excavations of Bronze Age Field Systems on Shovel Down, Dartmoor, 2003. Past, 45: 10-12.

Carlsson, D. 1979: Kulturlandskapets utveckling på Gotland. En studie av jordbruks- och bebyggelseförändringar under järnåldern. Visby: Press Förlag.

Chadwick, A.M. 2008. Introduction. In: A.M. Chadwick, ed. Recent Approaches to the Archaeology of Land Allotment (BAR International Series S1875). Oxford: Archaeopress, pp. 1-23.

Chadwick, A.M. 2013. Some Fishy Things About Scales: Macro and Micro Levels of Analysis in the Study of Later Prehistoric and Romano-British Field Systems. Landscapes, 14: 13-32.
Donat, P. 1992. Tacitus, Germania Kap 26.2 und das Problem der Celtic fields. Zeitschrift für Agrargeschichte und Agrarsoziologie, 40: 1-14.

Drew, K. 1973. The Lombard Laws. Philadelphia: University of Pennsylvania Press.

Eir, B. 1982. Måleenheder i Oldtidsagre. Aarboger for Nordisk Oldkyndighed og Historie, 1980: 100-13.

Fallgren, J. 2006. Kontinuitet och forrändring: Bebyggelse och sambälle på Öland 200-1300 e.Kr. Uppsala: Department of Archaeology and Ancient History, Uppsala University.

Fleming, A. 1987. Coaxial Field Systems: Some Questions of Time and Space. Antiquity, 61: 188-202.

Fokkens, H. 1998. Drowned Landscape: The Occupation of the Western Part of the Frisian-Drentian Plateau, 4400 BC-AD 500. Assen: Van Gorcum.

Fowler, P.J. 1967. The Archaeology of Fyfield and Overton Downs, Wiltshire: Third Interim Report. Wiltshire Archaeological and Natural History Magazine, 62: 16-33.

Fowler, P.J. 1971. Early Prehistoric Agriculture in Western Europe: Some Archaeological Evidence. In: D.D.A. Simpson, ed. Economy and Settlement in Neolitbic and Early Bronze Age Britain and Europe. Leicester: Leicester University Press, pp. 153-82.

Frandsen, K. 1988. The Field Systems of Southern Scandinavia in the 17th Century: A Comparative Analysis. Geografiska Annaler. Series B, Human Geography, 70: 117-21.

Gerritsen, F.A. 2003. Local Identities: Landscape and Community in the Late Prehistoric Meuse-Demer-Scheldt Region. Amsterdam: Amsterdam University Press.

Hagen, A. 1953. Studier $i$ jernalderens gårdssamfunn, (Universitetets oldsaksamling skrifter 6). Oslo: Universitetets oldsaksamling.

Hajek, B 1988. Cooling Schedules for Optimal Annealing. Mathematics of Operation Research, 13: 311-29.

Hannerberg, D. 1955. Die älteren skandinavischen Ackermasse: Ein Versuch zu einer zusammenfassenden Theorie. Lund: Royal University of Lund, Department of Geography \& Gleerup.

Hansen, S.S. 1979. Nogle aspekter omkring ejendomsformer og social arbejdsdeling $\mathrm{i}$ 
Danmarks yngre bronzealder og ældre jernalder. Et forsøg på en historisk placering af de såkaldte "Celtic Fields". Kontaktstencil, 16: 63-79.

Harris, E.C. 1975. The Stratigraphic Sequence: A Question of Time. World Archaeology, 7: 109-21.

Hatt, G. 1938. Jernalderens bopladser i Himmerland. Aarboger for Nordisk Oldkyndighed og Historie, 1938: 119-266.

Hatt, G. 1939. The Ownership of Cultivated Land. Copenhagen: Ejnar Munksgaard.

Hatt, G. 1949. Oldtidsagre. Copenhagen: Ejnar Munksgaard.

Herzog, I. 1993: Computer-aided Harris Matrix Generation. In: E.C. Harris, M.R. Brown \& G.J. Brown, eds. Practices of Archaeological Stratigraphy. London: Academic Press, pp. 201-17.

Holst, M.K. 2004. Complicated Relations and Blind Dating: Formal Analysis of Relative Chronological Structures. In: C.E. Buck \& A.R. Millard, eds. Tools for Constructing Chronologies: Crossing Disciplinary Boundaries. London: Springer, pp. 129-47.

Holst, M.K. 2010. Inconstancy and Stability: Large and Small Farmsteads in the Village of Nørre Snede (Central Jutland) in the First Millennium AD. Siedlungs- und Küstenforschung im südlichen Nordseegebiet (Settlement and Coastal Research in the Southern North Sea Region), 33: 155-79.

Holst, K.K. \& Holst, M.K. 2004, 29 March, last update. Tempo [online] [accessed 15 May 2009]. Available at: <http://publicifsv.sund.ku.dk/ kkho/tempo/>

Johnston, R. 2005. Pattern Without a Plan: Rethinking the Bronze Age Coaxial Field Systems on Dartmoor, South-West England. Oxford Journal of Archaeology, 24: $1-21$.

Kirkpatrick, S., Gelatt, C.D. \& Vechhi, M.P. 1983. Optimization by Simulated Annealing. Science 220 (4598): 671-80.

Klamm, M. 1993. Aufbau und Entstehung Eisenzeitlicher Ackerfluren ("Celtic Fields"). I. Stand der Forschung. Göttingen: Brunk Meyer.

Knuth, D. 1997. The Art of Computer Programming. Volume 1: Fundamental Algorithms. Reading: Addison Wesley.

Lang, V. 1994. Celtic and Baltic Fields in North Estonia: Fossil Field Systems of the Late Bronze Age and Pre-Roman Iron
Age at Saha-Loo and Proosa. Acta Archaeologica, 65: 203-19.

Lang, V. 2007. Estonian Archaeology 3: The Bronze and Early Iron Ages in Estonia. Tartu: Tartu University Press.

Lindquist, S.-O. 1974. The Development of the Agrarian Landscape on Gotland during the Early Iron Age. Norwegian Archaeological Review, 7: 6-32.

Løvschal, M. 2015. Lines of Landscape Organization: Skovbjerg Moraine (Denmark) in the First Millenium BC. Oxford Journal of Archaeology, 34: 259-78.

Müller-Wille, M. 1965. Eisenzeitliche Fluren in den festländischen Nordseegebieten. Münster: im Selbstverlag der Geographischen Kommission.

Müller-Wille, M. 1979. Flursysteme der Bronze- und Eisenzeit in den Nordseegebieten. Zum Stand der Forschung über "Celtic Fields". In: H. Beck, D. Denecke \& H. Jankuhn eds. Untersuchungen zur eisenzeitlichen und frübmittelalterlichen Flur in Mitteleuropa und ibrer Nutzung. Bericht über die Kolloquien der Kommission für die Altertumskunde Mittel- und Nordeuropas in den Jahren 1975 und 1976. Teil I (Abhandlungen der Akademie der Wissenschaften in Göttingen. Philologisch-historische Klasse. Dritte Folge, Nr. 115). Göttingen: Vandenhoeck \& Ruprecht, pp. 196-239.

Murray, A.C. 1983. Germanic Kinship Structures: Studies in Law and Society in Antiquity and the Early Middle Ages. Toronto: Pontifical Institute of Mediaeval Studies.

Nielsen, N.H. \& Dalsgaard, K. 2017. Dynamics of Celtic Fields: A Geoarchaeological Investigation of $\varnothing_{\text {ster Lem Hede, Western }}$ Jutland, Denmark. Geoarchaeology - An International Journal, 32, 414-34. doi 10.1002/gea.21615

Nielsen, V. 1993. Jernalderens plojning. Store Vildmose. Undersøgelser i Grishøjgärds Krat. Pløjeteknik. Gravhøje i Store Vildmose. Pløjespor under høje. Hjørring: Vendsyssel historiske Museum.

Nielsen, V. 2000. Oldtidsagre i Danmark. Bornholm. Højbjerg: Jysk Arkæologisk Selskab.

Nielsen, V. \& Clemmensen, N. 2010. Oldtidsagre i Danmark: Sjalland, Møn og Lolland-Falster. $\quad$ Højbjerg: Jysk Arkæologisk Selskab. 
Pihl, A. 2013. Oldtidsagre omkring Østersøen i 1. årtusinde f.kr (unpublished MA dissertation, Copenhagen University).

Pryor, F. 1998. Farmers in Prehistoric Britain. Stroud: Tempus.

Riles, A. 1998. Division within the Boundaries. Journal of the Royal Anthropological Institute, 4: 409-24.

Rindel, P.O. 1999. Development of the Village Community $500 \mathrm{BC}-100 \mathrm{AD}$ in West Jutland, Denmark. In: C. Fabech \& J. Ringtved, eds. Settlement and Landscape: Proceedings of a Conference in Arbus, Denmark. May 4-7 1998. Højbjerg: Jutland Archaeological Society, pp. 79-99.

Roymans, N. \& Gerritsen, F. 2002. Landscape, Ecology and Mentalités: A Long-term Perspective on Developments in the Meuse-Demer-Scheldt Region. Proceedings of the Prehistoric Society, 68: 257-87.

Sharon, I. 1995. Partial Order Scalogramanalysis of Relations: A Mathematical Approach to the Analysis of Stratigraphy. Journal of Archaeological Science, 22: 751-67.

Sørensen, P.H. 1973. Jysk oldtidsagerbrug lokaliseret efter luftfotografier. Kulturgeografi, 24: 337-54.

Sørensen, P.H. 1982. The Use of Air Photographs in Celtic Field Studies. Journal of Danish Archaeology, 1: 77-86.

Sporrong, U. 1995. Ägandets reproduktion om arvsregler och landskapsutveckling i 1700-talets Dalarna. In: M. Widgren, ed. Äganderätten $i$ lantbrukets bistoria. Stockholm: Nordiska Museet, pp. 99-108.

Steensberg, A. 1951. Modern Research of Agrarian History in Denmark. LAOS, 1: 187-201.

Veibæk, O. 1974. Ploven og dens betydning: med sarligt henblik på landsbyorganisation. Skanderborg: s.n.

Webley, L. 2008. Iron Age Households: Structure and Practice in Western Denmark, $500 \quad B C-A D 200 . \quad$ Højbjerg: Jutland Archaeological Society.

Wickstead, H. 2008. Theorising Tenure: Land Division and Identity in Later Prehistoric Dartmoor (British Archaeological Reports British Series 465). Oxford: Archaeopress.

Widgren, M. 1983. Settlement and Farming Systems in the Early Iron Age (Stockholm Studies in Human Geography 3). Stockholm: Acta Universitatis
Stockholmiensis.

Widgren, M. 1990. Strip Fields in an IronAge Context: A Case Study from Västergötland, Sweden. Landscape History, 12: 5-24.

Widgren, M. 1995. Individuellt eller kollektivt ägande i bondesamhällen? In: $M$. Widgren, ed. Äganderätten $i$ lantbrukets historia (Skrifter om skogs- og landbrukshistoria 8). Stockholm: Nordiska Museet, pp. 5-16.

Widgren, M. 2006. Reading Property in the Landscape. Norsk Geografisk Tidsskrift (Norwegian Journal of Geography), 60: $57-64$.

Yates, D.T. 2007. Land, Power and Prestige: Bronze Age Field Systems in Southern England. Oxford: Oxbow Books.

\section{Biographical Notes}

Nina Helt Nielsen is Head of Research at Museum Silkeborg. An earlier version of the current article was written as part of her $\mathrm{PhD}$ dissertation 'Formation of Celtic Fields: A geoarchaeological and relativechronological study of selected Danish field systems from the Late Bronze and Early Iron Age'. She is interested in geoarchaeology and how archaeological science can contribute to the understanding of prehistoric societies. She continues her research on Celtic fields, but is also involved in studies of Tollund Man and other research projects at the museum.

Address: Museum Silkeborg, Hovedgårdsvej 7, 8600 Silkeborg, Denmark. [email: nhn@ museumsilkeborg.dk]

Mads Kähler Holst has been Director of Moesgård Museum since December 2016. Before that, he was professor at Aarhus University and Head of the Department of Archaeology at Moesgaard Museum. He focuses on settlement organization and societal changes in the Iron Age and has 
led several large research and excavation projects, including that of Jelling. He has also been engaged in developing research infrastructure and natural sciences applications in archaeology as well as investigating Bronze Age cosmologies, landscape use and barrow building.

Address: Department of Archaeology, Aarhus University, Moesgård Allé 20, 8270 Højbjerg, Denmark/Moesgaard Museum, Moesgård Allé 15, 8270 Højbjerg, Denmark. [email: mkh@moesgaardmuseum.dk]

Ann Catherine Gadd has a Master's degree in Prehistoric Archaeology from Aarhus University and as part of her degree she undertook research on Danish Celtic field systems and their layout. She currently works as a field archaeologist at Museum Midtjylland in Herning, Denmark.

Address: Museum Midtjylland, Vestergade 20, 7400 Herning, Denmark. [email: ann_gadd@hotmail.com]

Klaus Kähler Holst is associate professor at the Section of Biostatistics, University of Copenhagen. His research focuses on computational statistics and statistical methods for multivariate endpoints with applications in neuroimaging and family studies.

Address: Department of Biostatistics, Copenhagen University, Øster Farimagsgade 5 opg. B. Postboks 2099, 1014 Copenhagen K, Denmark. [email: k.k.holst@biostat.ku. $\mathrm{dk}]$

\section{Organisation et évolution interne des " champs celtiques " : analyse structurelle et chronologie relative de trois " champs celtiques " au Danemark}

La configuration et l'évolution des "champs celtiques " peuvent révéler des aspects importants des sociétés prébistoriques telles que les stratégies de production agricole, les droits d'utilisation et les coutumes concernant les héritages. Cet article présente une méthode permettant d'analyser l'évolution des "champs celtiques " dans leur intégralité, sur la base d'un classement biérarchique des limites de parcelles dont les intersections ont été utilisées pour définir leurs relations d'équivalence et de subordination. L'analyse de l'expression relationnelle formalisée du parcellaire se fait grâce à un algorithme d'optimisation stochastique. Cette méthode a été appliquée avec succès à trois "champs celtiques " au Danemark datant de la fin de l'âge du Bronze et du début de l'âge du Fer, ce qui nous a permis d'identifier cing principes régissant la configuration des champs : limites primaires (probablement établies par les communautés), parcelles majeures (gérées au niveau des foyers), découpage structuré (vraisemblablement lié au patrimoine héréditaire), subdivisions irrégulières et croissance à petite échelle du système parcellaire. Le degré de régularité à l'origine de l'aménagement du terrain semble avoir influencé les modifications ultérieures. Translation by Madeleine Hummler

Mots-clés: « champs celtiques ", aménagement du terrain, chronologie relative, classement stochastique, âge du Bronze récent/premier âge du Fer

\section{Aufbau und interne Entwicklung der "Celtic Fields": strukturelle und relativ- chronologische Auswertung von drei dänischen Ackersystemen}

Der Aufbau und die Entwicklung von Ackersystemen können wesentliche Aspekte der urgeschichtlichen Gesellschaften, wie landwirtschaftliche Strategien, Landnutzungsgerechte oder Erbvorgänge zum 
Vorschein bringen. In diesem Artikel wird eine Methode, welche zur Untersuchung der Entwicklung von ganzen Ackersystemen beitragen kann; vorgelegt sie stützt sich auf die hierarchische Sortierung der Feldgrenzen, deren Kreuzungspunkte zur Bestimmung von Äquivalenzbeziehungen und Unterordnungsverhältnisse dienen. Der formalisierte Vergleichsausdruck der Flursysteme wird durch einen stochastischen Optimierungsalgorithmus analysiert. Diese Methode wurde erfolgreich zur Auswertung von drei dänischen spätbronzezeitlichen und früheisenzeitlichen Ackersystemen angewendet; dabei war es möglich fünf Grundregeln, welche die Anlage von Äckern bestimmen, zu identifizieren: vorrangige Grenzen (wahrscheinlich von Gemeinschaften eingerichtet), wesentliche Grundstücke (auf Haushaltsebene betrieben), strukturierte Untergliederung (vermutlich mit Erbschaft verbunden), unregelmäßige Unterteilungen, und Erweiterung der Flursysteme auf geringem Maße. Die ursprüngliche Regelmäßigkeit der Ackersysteme scheint die späteren Änderungen beeinflusst zu haben. Translation by Madeleine Hummler

Stichworte: Ackersysteme, "Celtic Fields", Grundrisse, Erbschaft, relative Chronologie, stochastische Sortierung, Spätbronzezeit/frühe Eisenzeit 